\title{
Incorporation of oat flour into wheat flour noodle and evaluation of its physical, chemical and sensory attributes
}

\author{
Incorporação de farinha de aveia em noodle de farinha de trigo \\ e avaliação de seus atributos físicos, químicos e sensoriais
}

\author{
Md. Suzauddula1,2 (D), Md. Bellal Hossain ${ }^{1}$, Tasnim Farzana ${ }^{3}$, Tania Nowreen Orchy ${ }^{3}$, \\ Md. Numan Islam ${ }^{4}$, Md. Mahmudul Hasan ${ }^{4 *}$ (D)
}

${ }^{1}$ Daffodil International University, Department of Nutrition and Food Engineering, Dhaka - Bangladesh

${ }^{2}$ National Chung Hsing University, College of Agriculture and Natural Resources, Taichung - Taiwan

${ }^{3}$ Bangladesh Council of Scientific and Industrial Research, Institute of Food Science and Technology, Dhaka -

Bangladesh

${ }^{4}$ Jashore University of Science and Technology, Department of Nutrition and Food Technology, Jashore -

Bangladesh

${ }^{*}$ Corresponding Author: Md. Mahmudul Hasan, Jashore University of Science and Technology, Department of Nutrition and Food Technology, 7408, Jashore - Bangladesh, e-mail: hasanm_agb@yahoo.com

Cite as: Suzauddula, M., Hossain, M. B., Farzana, T., Orchy, T. N., Islam, M. N., \& Hasan, M. M. (2021).

Incorporation of oats flour into wheat flour noodles and evaluation of its physical, chemical and sensory attributes.

Brazilian Journal of Food Technology, 24, e2020252. https://doi.org/10.1590/1981-6723.25220

\begin{abstract}
Noodles are popular food and fortified noodles with vital nutrients may build a healthy food habit among people. Oat is a cereal with high nutritional value. Therefore, the current research was undertaken to increase the nutrient content of noodles using oat flour and to evaluate the effects of oat flour on the physicochemical properties and sensory attributes of the noodles. The noodles were prepared following five different formulations (oats: wheat flour in the ratio of 0:100, 20:80,25:75, 30:70 and 35:65). Other ingredients like table salt, carboxymethyl cellulose (CMC), corn starch, and water were equal in each formulation. To evaluate the best formulation, proximate analysis, functional characteristics and sensory assay were conducted on samples. The formulation having $70 \%$ of wheat flour and $30 \%$ of oat flour showed the best performance in proximate analysis and sensory evaluation. This formulation of noodles has $13.03 \%$ of protein, $1.51 \%$ of fat, $1.46 \%$ of total ash, $0.76 \%$ of fibre, $73.87 \%$ of carbohydrate, 361.19 kcal of energy and also a good amount of important minerals. The formulation regarding wheat flour $70 \%$ and oat flour $30 \%$ may be suggested to the large population who are habituated to consume noodles regularly as the main diet.
\end{abstract}

Keywords: Oat; Noodles; Physiochemical properties; Wheat; Noodles formulation; Sensory attributes.

\section{Resumo}

Macarrão tipo noodle é um alimento popular e macarrão fortificado com nutrientes vitais pode criar um hábito alimentar saudável entre as pessoas. A aveia é sabidamente um cereal de alto valor nutritivo, o que motivou esta pesquisa: buscou-se aumentar o teor de nutrientes do macarrão tipo noodle usando farinha de aveia e avaliar os efeitos desse acréscimo nas propriedades físico-químicas e nos atributos sensoriais do macarrão. $\mathrm{O}$ macarrão foi 
preparado seguindo cinco formulações diferentes com a relação aveia:farinha de trigo nas proporções de 0:100, 20:80, 25:75, 30:70 e 35:65. Outros ingredientes, como sal de cozinha, carboximetilcelulose (CMC), amido de milho e água, foram mantidos na mesma proporção em todas formulações. Para avaliar a melhor formulação, análises de composição centesimal, características funcionais e sensoriais foram realizadas nas amostras. A formulação contendo a relação $70 \%$ de farinha de trigo e $30 \%$ de farinha de aveia apresentou melhor composição centesimal e melhor desempenho na avaliação sensorial. Esta formulação de macarrão possui 13,03\% de proteína, 1,51\% de gordura, $1,46 \%$ de cinzas totais $0,76 \%$ de fibra, $73,87 \%$ de carboidrato $361,19 \mathrm{kcal}$ e uma expressiva quantidade de minerais importantes. A formulação com $70 \%$ de farinha de trigo e $30 \%$ de farinha de aveia é recomendada para a população que está habituada a consumir macarrão regularmente como dieta principal.

Palavras-chave: Aveia; Macarrão tipo noodle; Propriedades físico-químicas; Trigo; Formulação de macarrão; Atributos sensoriais.

\section{Introduction}

Noodles are popular food in almost all over the world due to high palatability and fast cooking properties (Aydin \& Gocmen, 2011). Based on ingredients used, noodles are categorized into White Salted Noodles (WSN) and Yellow Alkaline Noodles (YAN) (Asenstorfer et al., 2006). Traditional noodles are tasty and enriched in carbohydrate, however, less enriched in protein, minerals, dietary fibers and vitamins (Kudake et al., 2017). Wheat flour is considered as raw ingredient of noodles and in milling process around $18.34 \%$ of protein, $38.4 \%$ of fat, $72.77 \%$ of insoluble dietary fiber, $58.73 \%$ of ash and $70 \%$ of vitamins was loosed from it (Oghbaei \& Prakash, 2013, 2016). Supplementing or fortifying noodles by nutrient-enriched ingredients could add extra nutrients to the traditional noodles. Sequentially replacing 10, 20, 30, 40 and 50\% of wheat flours by ragi flour improved nutrition in noodles (Kulkarni et al., 2012). Finger millet flour (30\%) fortified noodles showed reduction of Glycemic Index (GI) than noodles made from wheat flour (45.13 vs 62.59 in wheat flour) (Shukla \& Srivastava, 2014). Noodles that characterize the foremost end-use of wheat flour are appropriate for enhancing healthiness while fusing with principle nutrients (Choo \& Aziz, 2010). Due to having high nutritional values and fiber content, oats may be added to improve nutritional quality of noodles.

The oat is characterized as starchy grain and easily cultivatable in all over the world. Oats have high percentage of protein $(17 \%)$, fat (7\%), carbohydrate $(66 \%)$, fiber $(11 \%)$, ash $(1.56 \%$ to $0.10 \% \mathrm{Ca}, 0.23 \% \mathrm{P})$, tryptophan $(0.17 \%)$, threonine $(0.36 \%)$, lysine $(0.41 \%)$, cysteine $(0.34 \%)$, methionine $(0.21 \%)$ and $\beta$-D gluten (Thies et al., 2014; Welch, 1995). The $\beta$-D gluten among oats is not only important for its nutritional and health application but also its water-binding capacity (between 3.14 and $4.52 \mathrm{~g} \mathrm{~g}^{-1}$ ) (Thies et al., 2014). Whole oats are the only source of a unique group of antioxidants called avenanthramides $(137.84 \mu \mathrm{g} / \mathrm{g})$ (Manzoor et al., 2020). Avenanthramides have preventive and treatment capacity of aging-related human diseases associated with oxidative stress and inflammation, including dermatological, cardiovascular, cerebrovascular, neurodegenerative properties, as well as metabolic disease and cancer (Perrelli et al., 2018). Oats is associated with reducing the risk of type-II diabetes (having low GI value and high fiber content), hypertension and cardiovascular disease due to significant reduction of total cholesterol level ( $2 \%$ to $23 \%)$ (Hou et al., 2015; Thies et al., 2014). Ahmad et al., investigated the market and explained that foods processed with oats have significant demand as a healthy food (Ahmad et al., 2010). The consumption of noodles has become significantly greater during the last 20 years (Mahmoud et al., 2012). It is a great opportunity to provide nutrition among people by fortifying the noodles with protein, fiber, iron, iodine, vitamins etc. On the other hand, noodles have comparative low price and people will easily be afforded it with enjoyment.

Noodles fortified with cereals showed significant qualitative improvement. Oats flour $(0,10,20,30$ and $40 \% \mathrm{w} / \mathrm{w}$ ) fortified noodles improves rheological properties of dough (Majzoobi et al., 2014). Continuously 
replacing wheat flour with oats flour improves chemical and sensory properties in noodles (Kudake et al., 2017; Chauhan et al., 2018). Oat and oat products have significant health benefits that increase the consumer awareness to this cereal (Liu et al., 2020). However, no research has been published to evaluate how physical, chemical and sensory attributes have been changed in oat fortified noodles. To considering the gap of previous research the current research was undertaken to develop acceptable formulation of noodles supplemented with oats flour and evaluate its physical, chemical, and sensory attributes.

\section{Materials and methods}

The materials like Wheat Flour (WF) (all-purpose refined wheat flour), Oats Flour (OF) (ACI Nutrilife Atta Oat Plus), cooking salt, carboxymethyl cellulose (CMC) and corn starch were procured from the near market of Bangladesh Council for Scientific and Industrial Research, Dhanmondi, Dhaka, Bangladesh. Food grade stainless steel utensils accessories (SS 304) and Imperia pasta maker machine (Model 150, Italy) were used during noodles preparation. Proximate analysis such as moisture, protein, fat, fiber and ash (sub section 2.2, 2.3.2.4, 2.5 and 2.6 accordingly) content of raw OF, WF and sample noodles were examined using Official methods of analysis AOAC 2005 (Association of Analytical Communities) with little modification (Horwitz \& Latimer, 2005).

\subsection{Preparation of control and sample noodles}

For the preparation of control noodles, $25 \mathrm{~g}$ sieved WF was mixed with $0.50 \%$ of CMC, $4.65 \%$ of cooking salt and $4.50 \%$ of corn starch in $110 \mathrm{~mL}$ tap water. Dough ball was prepared to make a pasta sheet by following the "two-stage mixing" process. Before preparing pasta sheet, the dough balls were kept 15-30 min covering in a bowl with a wet towel to keep the dough soften and activate sulfur-sulfur bond (Singh et al., 2019).

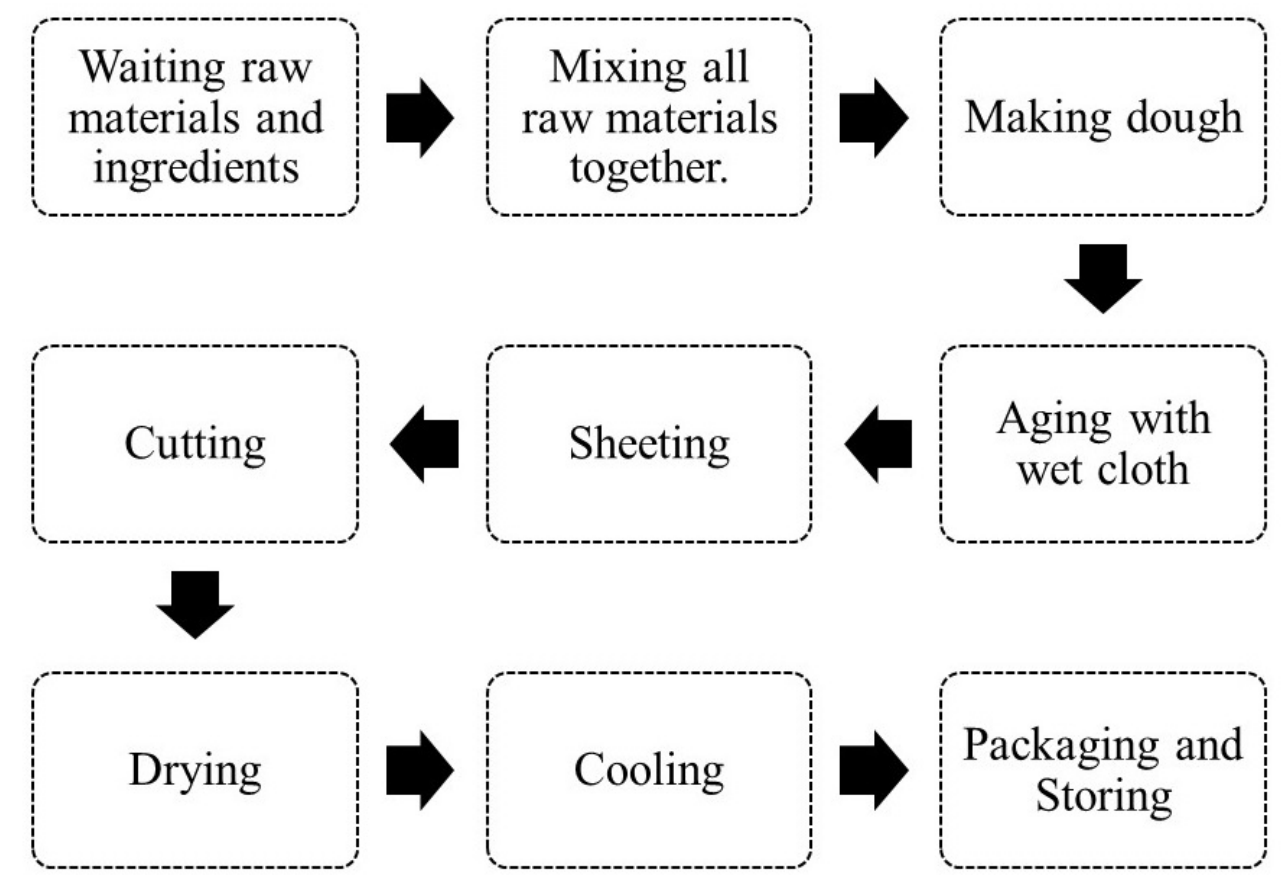

Figure 1. Process flow chart regarding the noodle production.

Then, the pasta sheet was prepared by folding and passing several times through the plain rollers of the noodle machine. The thickness of the pasta sheet was gradually reduced by minimizing the roller space. In 
addition, the pasta sheet was cut pouring into $4 \mathrm{~mm}$ thick mold. After cutting the sheets, noodles were air dried for around $6-7 \mathrm{~h}$ at room temperature to loss maximum moisture. To make the fortified samples, $20 \%$, $25 \%, 30 \%$ and $35 \%$ of OF were replaced with WF, however, the other ingredients were the same as control noodles (Table 1). Other process was the same as like plain noodles preparation (Figure 1). Each of the samples was prepared in triplicate. After drying, the sample noodles were collected and packed in a polypropylene zipper bag (Figure 2).

Table 1. Formulations of noodles (S).

\begin{tabular}{cccccc}
\hline Ingredients & S0 & S1 & S2 & S3 & S4 \\
\hline Wheat flour (\%) & 100.00 & 80.00 & 75.00 & 70.00 & 65.00 \\
\hline Oat flour (\%) & 00.00 & 20.00 & 25.00 & 30.00 & 35.00 \\
\hline Corn starch (\%) & 4.50 & 4.50 & 4.50 & 4.50 & 4.50 \\
\hline Salt (\%) & 1.65 & 1.65 & 1.65 & 1.65 & 1.65 \\
\hline CMC (\%) & 0.50 & 0.50 & 0.50 & 0.50 & 0.50 \\
\hline Water (mL) \pm 5 & 110 & 110 & 110 & 110 & 110 \\
\hline
\end{tabular}

\subsection{Determination of the moisture content}

Approximately $5.0 \mathrm{~g}$ of each sample as given into dry oven at $105{ }^{\circ} \mathrm{C}$ temperature and after 5 to $6 \mathrm{~h}$ the evaporated volume was noted as moisture content.

\subsection{Determination of the protein content}

Protein contents were determined by the classical Kjeldahl method. Where $0.2 \mathrm{~g}$ of sample was taken in a cleaned and dried digestion tube at which digestion mixture $\left(\mathrm{K}_{2} \mathrm{SO}_{4}\right.$ and $\left.\mathrm{Cu}\right)$ and $10.00 \mathrm{~mL}$ of concentrated $\mathrm{H}_{2} \mathrm{SO}_{4}$ were added. The mixture was digested by continues heating till the fumes could be seen. After digestion, solution was cooled and the volume was made to $100 \mathrm{~mL}$ with distilled water. Then $10 \mathrm{~mL}$ of diluted sample and $40 \%$ of $\mathrm{NaOH}$ were transferred into Kjeldahl distillation flask. Then the essence was collected through distillation in conical flask where $10 \mathrm{~mL} 0.1 \mathrm{~N} \mathrm{HCl}$ was taken and 1 to 2 drop of methyl red was added. Finally, the sample was titrated against $0.1 \mathrm{~N} \mathrm{NaOH}$ till the colour changed from pink to yellow. The same procedure was carried out for the blanks (Formula 1).

$\%$ of Protein $=\frac{(\text { Titration Value of Blank }- \text { Titration Value of sample }) \times 1.4 \times 6.25 \times \text { strenght of } \mathrm{NaOH}(.099) \times 10}{\text { Weight of sample taken }}$

\subsection{Determination of the fat content}

Fat was estimated as crude ether extract of dry material. Total $15 \mathrm{~g}$ of grained sample was taken in a thimble and extract fat within a fat free dried Soxhlet flask with $\mathrm{C}_{6} \mathrm{H}_{14}$ for $48 \mathrm{~h}$. After the period, $\mathrm{C}_{6} \mathrm{H}_{14}$ (contained fat) was poured into a conical flask and heated $\left(65^{\circ} \mathrm{C}\right)$ with a hot plate. After evaporation of $\mathrm{C}_{6} \mathrm{H}_{14}$ the conical flask was cooled in desiccators and then measured the fat content (Formula 2).

$\%$ of Fat $=\frac{\text { Weight of the conical with fat }- \text { Weight of the empty conical }}{\text { Weight of sample taken }}(100)$

\subsection{Determination of the crude fiber content}

To determine the crude fiber, $20 \mathrm{~g}$ of dried, fat free and crushed noodles were taken into a conical flask contained $200 \mathrm{~mL}$ of $\mathrm{H}_{2} \mathrm{SO}_{4}$. The solution was boiled for $30 \mathrm{~min}$ with bumping chips with occasional rotation. Then, the content into flask was filtered through muslin and washed with boiled water. Wash residue was 
transferred back to the flask by spatula and again boiled for 30 min with bumping chips in $200 \mathrm{~mL} \mathrm{of} \mathrm{NaOH}$. Then it was filtered and washed as previous way then the residue was transferred to a crucible and dried at $110{ }^{\circ} \mathrm{C}$ for $2 \mathrm{~h}$. After drying and noted the weight, the samples were ignited for $20 \mathrm{~min}$ at $600{ }^{\circ} \mathrm{C}$ then the weight of burned particle was noted (Formula 3 ).

$\%$ of Crude fiber $=\frac{\text { Weight after drying at } 110^{\circ} \mathrm{C}-\text { Weight after drying at } 600^{\circ} \mathrm{C}}{\text { Weight of sample taken }}(100)$

\subsection{Determination of the ash content}

To estimate the ash content, $1.5 \mathrm{~g}$ of sample was taken into a dried and weighted crucible. Then, the crucible was placed onto a gas burner for primary combustion (heated order: low-medium-high) and after combustion the crucible was heated for 6 to $7 \mathrm{~h}$ at $700{ }^{\circ} \mathrm{C}$. After that period, the crucible was then cooled in desiccator and weighted (Formula 4).

$\%$ of Ash $=\frac{\text { (Weight of the crucible }+ \text { Sample after combussion })- \text { Weight of crucible }}{\text { Sample taken }}(100)$

\subsection{Estimation of the carbohydrate and calorie content}

The percentage of utilizable carbohydrates in the noodles samples was calculated by subtracting the protein, fat, moisture and crude fiber from 100 (Mertens, 2005). The calorie of samples noodles was calculated with the Atwater's conversion factor, $9 \mathrm{kcal} / \mathrm{g}$ for fat and $4 \mathrm{kcal} / \mathrm{g}$ for carbohydrate and protein (Sánchez-Peña et al., 2017).

\subsection{Determination of the mineral content}

Mineral content such as Calcium (Calcium), Sodium (Na) and Potassium (K) contents were estimated by using a Systronics Type 130 flame photometer and following standard protocol (Eneche, 1999; Parvin et al., 2020). The used reagents and chemicals were analytical grades (Sigma Aldrich). The working solutions were diluted to make them suitable for measuring each mineral (100 ppm Ca, $200 \mathrm{ppm} \mathrm{Na}$ and $200 \mathrm{ppm} \mathrm{K}$ ) from the stock (standard) solutions (1000 $\mu \mathrm{g} / \mathrm{mL})$. Then, $01 \mathrm{~g}$ of sample noodles was mixed with $20 \mathrm{~mL}$ of a di-acid mixture $\left(4 \mathrm{HNO}_{3}: 1 \mathrm{HClO}_{4}\right)$ and poured into a conical flask $(100 \mathrm{~mL})$. To digest the sample, around $60-70{ }^{\circ} \mathrm{C}$ temperature was applied with a magnetic hot plate to obtain a colorless liquid (Somvanshi et al., 2017).

The amount of Iron was measured by the Flame Atomic Absorption Spectrophotometer (FAAS) at 248.3-327 $\mathrm{nm}$ wavelength (Eneche, 1999). The sample noodles (5 to $15 \mathrm{~g}$ ) were dried in a drying oven at $221^{\circ} \mathrm{F}$ for $3.0 \mathrm{~h}$ following burnt in muffle furnace at $600^{\circ} \mathrm{C}$ to collect the residue (ash). The residue was poured into a $100 \mathrm{~mL}$ of volumetric flask and $50 \mathrm{~mL}$ of concentrated HCL (hydrochloric acid) was added to it. As standard solution, ferric nitrate $\left(\mathrm{FeN}_{3} \mathrm{O}_{9}\right)$ was used and the amount of iron in the noodles was calculated comparing with the standard curve (Siong et al., 1989; Pearson, 1999). A calibration curve with five concentrations $(0.5,1.0,1.5,2.0,2.5 \mathrm{mg} / \mathrm{L})$ of iron within the analytical range was prepared. Concentrations of iron in test solutions (of noodles) were calculated from the standard curve prepared. 


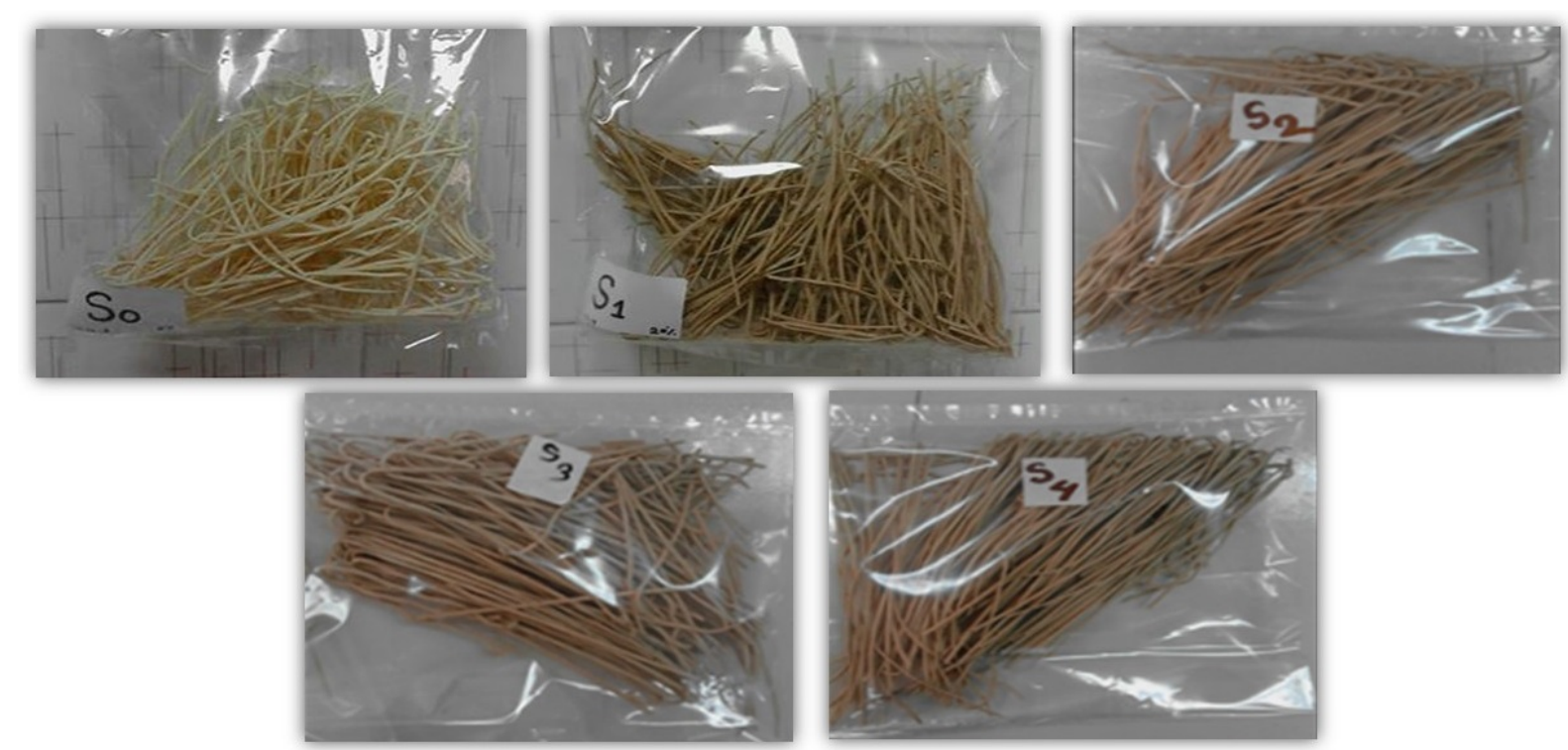

Figure 2. Dried sample noodles (S0, S1, S2, S3, S4 contain 0:100, 20:80, 25:75, 30:70 and 35:65 percentage of oats and wheat flour, respectively).

\subsection{Water absorption capacity (WAC)}

Water Absorption Capacity (WAC), cooling loss, volume increase and cooking time of each sample were processed for analysis following standard procedures (Figure 3).

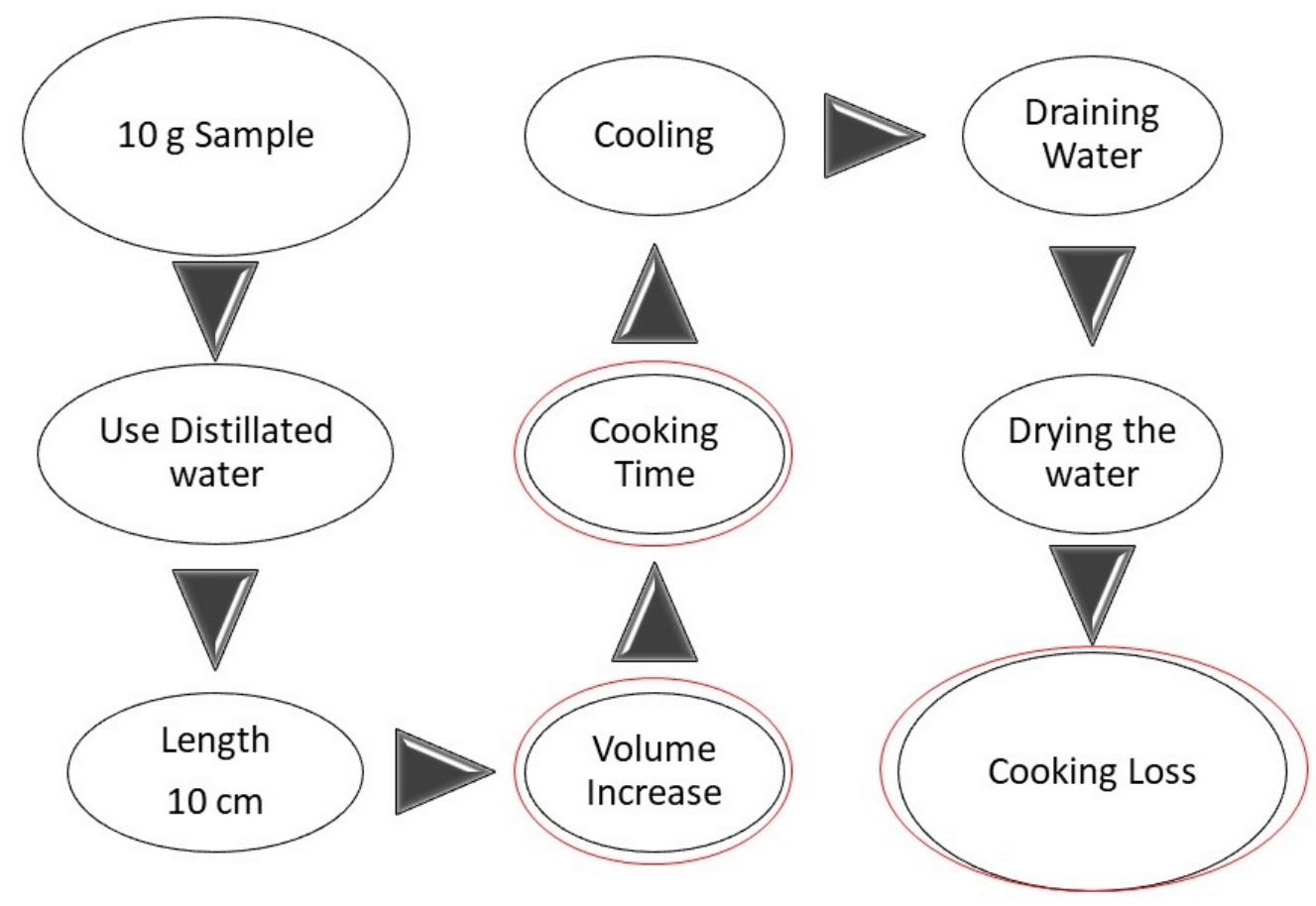

Figure 3. Process flow chart for identifying physical properties.

The WAC was measured by cooking $10 \mathrm{~g}$ of fresh noodles in $150 \mathrm{~mL}$ of water for optimum cooking period. After cooling for $5 \mathrm{~min}$ in a cold-water bath, the excess water was drained for 30s and WAC was calculated according to the following Formula 5 (American Association of Cereal Chemists, 2010). 
WAC $(\%)=\frac{\text { Weight of Cooked Noodles }(\mathrm{g})-\text { Weight of fresh noodles }(\mathrm{g})}{\text { Weight of fresh noodles }(\mathrm{g})} \mathrm{X100}$

\subsection{Cooking Loss}

The cooking losses regarding the formulations of noodles were measured following standard procedures (American Association of Cereal Chemists, 2010). Simply, to identify the cooking loss, $25 \mathrm{~g}$ of sample noodles were cooked (boiled) following optimum cooking time in $250 \mathrm{~mL}$ of tap water. The cooked water was drained in a beaker then dried at $105^{\circ} \mathrm{C}$ in a drying oven until the total water dried and the percentage of cooking loss was calculated following standard Formula 6 (Chakraborty et al., 2003).

Cooking loss $(\%) \quad=\frac{\text { Remaining solid content after drying }(\mathrm{g})}{\text { Weight of fresh noodles }(\mathrm{g})} \mathrm{X} 100$

\subsection{Volume increase and optimum cooking time}

The volume increase was identified as the percentage varies between the volume of cooked and uncooked noodles. For this, $25 \mathrm{~g}$ of cooked and uncooked noodles were put into $300 \mathrm{~mL}$ of water in a $500 \mathrm{~mL}$ of measuring cylinder. The volume increase was calculated according to the following Formula 7.

Volume increase $(\%)=\frac{\text { Volum of Cooked Noodles }(\mathrm{ml})-\text { Volume of fresh noodles }(\mathrm{ml})}{\text { Volume of fresh noodles }(\mathrm{ml})}$ X100

The optimum cooking time was corresponded to the disappearance of the white core of noodles after being squeezed between two glasses (Bhise et al., 2015). After conducting two to three trials, optimum cooking time was identified.

\subsection{Sensory analysis}

The sensory analyses were assessed by subjecting the cooked sample noodles by seven in-house semi and highly skilled panelist age ranged 25 to 35 years and were worked to assure food quality at Bangladesh Council for Scientific and Industrial Research, Bangladesh. The scores were obtained on a 9-point hedonic scale where scored them from 1 to 9 (low score 1 for dislike extremely and top score 9 for like extremely). The test was done in separate booths and maintained standard taste panel area under daylight illumination.

\subsection{Statistical analysis}

The data was analyzed using the Analysis of Variance (ANOVA) by the method of Snedecor and Cochran using Completely Randomized Design (CRD) (Snedecor \& Cochran, 1994). Statistical analysis was carried out by using IBM SPSS ${ }^{\circledR} 20.0$ for Windows ${ }^{\circledR}$. The means were separated using Duncan's test at $p<0.05$.

\section{Result and discussion}

The difference between the proximate composition of OF and WF are given in Table 2 . The selected WF for noodles preparation was contained $10.84 \%$ of protein, $0.26 \%$ of minerals, $0.21 \%$ of crude fiber, $1.20 \%$ of fat and $78.11 \%$ of carbohydrate which was in agreement with the earlier results $(10.68 \%$ to $10.73 \%, 1.49 \%$ to $1.52 \%, 0.47 \%$ to $0.51 \%, 1.15 \%$ to $1.17 \%$ and $76.44 \%$ to $76.46 \%$, respectively) and reported by (Kudake et al., 2017; Bhalerao et al., 2018). The chemical composition obtained from oats flour $(7.39 \%$ of 
moisture, $17.06 \%$ of protein, $2.62 \%$ of fat, $2.55 \%$ of fiber and $2.44 \%$ of ash) was also similar with the study conducted by Vollmann (Vollmann et al., 2004).

Table 2. Comparison of oats flour and wheat flour compositions used for noodle preparation

\begin{tabular}{ccc}
\hline Nutrients & OF & WF \\
\hline Moisture (\%) & $7.39 \pm 0.11$ & $9.74 \pm 0.15$ \\
\hline Protein (\%) & $17.06 \pm 0.31$ & $10.84 \pm 0.22$ \\
\hline Ash (\%) & $2.44 \pm 0.01$ & $0.26 \pm 0.02$ \\
\hline C. Fiber (\%) & $2.55 \pm 0.01$ & $0.21 \pm 0.01$ \\
\hline Fat (\%) & $2.62 \pm 0.09$ & $1.20 \pm 0.06$ \\
\hline CHO (\%) & $67.97 \pm 0.45$ & $78.11 \pm 0.50$ \\
\hline Energy (kcal) & $363.70 \pm 0.98$ & $366.60 \pm 0.75$ \\
\hline Calcium (mg) & $8.94 \pm 0.45$ & $7.58 \pm 0.32$ \\
\hline Potassium (mg) & $534.98 \pm 0.71$ & $132.70 \pm 0.21$ \\
\hline Sodium $(\mu \mathrm{g})$ & $403.13 \pm 0.89$ & $100.15 \pm 0.39$ \\
\hline Iron $(\mathrm{mg})$ & $6.01 \pm 0.12$ & $5.10 \pm 0.09$
\end{tabular}

Values are means of triplicates \pm Standard Deviation. OF: oat flour. WF: wheat flour.

\subsection{Noodles characteristics}

In this study, formulations S0, S1, S2, S3 and S4 were prepared with $0 \%, 20 \%, 25 \%, 30 \%$ and $35 \%$ of OF, respectively. The fiber content of OF regarding incorporated noodles S1, S2, S3 and S4 were $0.47 \%, 0.63 \%$, $0.76 \%$ and $0.87 \%$, respectively. Other nutrients such as protein, fat, ash, and energy content of noodles incorporated with oats flour were increased as compared to control (S0). The percentage of moisture and carbohydrate were decreased gradually with supplementing OF (Table 3).

Table 3. Proximate composition analysis of control and experimental noodles (per $100 \mathrm{~g}$ ).

\begin{tabular}{|c|c|c|c|c|c|c|c|c|c|c|c|}
\hline Formulations & $\begin{array}{c}\text { Protein } \\
(\%)\end{array}$ & $\begin{array}{l}\text { Fat } \\
(\%)\end{array}$ & $\begin{array}{l}\text { Ash } \\
(\%)\end{array}$ & $\begin{array}{c}\text { Moisture } \\
\text { (\%) }\end{array}$ & $\begin{array}{c}\text { Fiber } \\
(\%)\end{array}$ & $\begin{array}{c}\mathrm{Ca} \\
(\mathrm{mg}) \\
\end{array}$ & $\begin{array}{c}\mathrm{Fe} \\
(\mathrm{mg})\end{array}$ & $\begin{array}{c}\mathrm{Na} \\
(\mathrm{mg})\end{array}$ & $\begin{array}{c}\mathrm{K} \\
(\mathrm{mg})\end{array}$ & $\begin{array}{c}\text { CHO } \\
(\%)\end{array}$ & $\begin{array}{r}\text { Energy } \\
\text { (kcal) }\end{array}$ \\
\hline S0 & $9.28 \pm 0.11^{\mathrm{b}}$ & $1.16 \pm 0.24^{\mathrm{b}}$ & $1.69 \pm 0.27^{\mathrm{c}}$ & $9.50 \pm 0.46^{\mathrm{a}}$ & $0.14 \pm 0.05^{\mathrm{ac}}$ & $8.51 \pm 0.16^{\mathrm{a}}$ & $3.49 \pm 0.15^{\mathrm{b}}$ & $636.20 \pm 0.52^{\mathrm{a}}$ & $152.17 \pm 0.53^{\mathrm{b}}$ & 78.23 & 360.48 \\
\hline S1 & $10.92 \pm 0.20^{\mathrm{b}}$ & $1.37 \pm 0.25^{\mathrm{a}}$ & $1.75 \pm 0.13^{\mathrm{d}}$ & $9.35 \pm 0.25^{\mathrm{a}}$ & $0.47 \pm 0.05^{\mathrm{ab}}$ & $11.51 \pm 0.48^{\mathrm{c}}$ & $3.46 \pm 0.19^{\mathrm{a}}$ & $660.03 \pm 0.19^{\mathrm{ac}}$ & $170.58 \pm 0.29^{d}$ & 76.14 & 360.57 \\
\hline S2 & $12.20 \pm 1.0^{\mathrm{c}}$ & $1.49 \pm 0.20^{\mathrm{c}}$ & $1.79 \pm 0.23^{\mathrm{ab}}$ & $9.34 \pm 0.22^{\mathrm{b}}$ & $0.63 \pm 0.01^{\mathrm{b}}$ & $11.70 \pm 0.25^{\mathrm{b}}$ & $3.53 \pm 0.27^{\mathrm{c}}$ & $726.91 \pm 0.44^{\mathrm{b}}$ & $181.55 \pm 0.90^{\mathrm{c}}$ & 74.86 & 361.65 \\
\hline S3 & $13.03 \pm 0.50^{\mathrm{ab}}$ & $1.51 \pm 0.31^{\mathrm{bc}}$ & $1.86 \pm 0.22^{\mathrm{d}}$ & $9.19 \pm 0.34^{\mathrm{bd}}$ & $0.76 \pm 0.02^{\mathrm{a}}$ & $12.24 \pm 0.39^{d}$ & $3.32 \pm 0.21^{\mathrm{b}}$ & $797.12 \pm 0.49^{\mathrm{d}}$ & $200.24 \pm 0.03^{\mathrm{b}}$ & 73.87 & 361.19 \\
\hline S4 & $14.19 \pm 0.18^{\mathrm{a}}$ & $1.55 \pm 0.29^{\mathrm{ab}}$ & $1.62 \pm 0.50^{\mathrm{c}}$ & $9.11 \pm 0.11^{\mathrm{c}}$ & $0.87 \pm 0.02^{\mathrm{b}}$ & $12.26 \pm 0.31^{\mathrm{ac}}$ & $3.86 \pm 0.41^{\mathrm{c}}$ & $833.42 \pm 0.55^{\mathrm{c}}$ & $258.02 \pm .27^{\mathrm{ac}}$ & 72.66 & 361.35 \\
\hline $\begin{array}{c}\mathrm{CD} \\
(p=0.05)\end{array}$ & 0.28 & 0.92 & 0.35 & 0.84 & 0.09 & 0.01 & 0.01 & 0.07 & 0.01 & & \\
\hline
\end{tabular}

Values are means of triplicates \pm Standard Deviation.

In addition, early studies have shown that the incorporation of oats flour supports to decreased moisture contents ( $7.42 \%$ to $6.90 \%$ ) and carbohydrate contents (from $80.32 \%$ to $71.23 \%$ ) (Aydin \& Gocmen, 2011; Chauhan et al., 2018). As all other ingredients were the same except oats flour, in which the variation in nutrition content was due to the addition of oats flour. Mineral contents of noodles containing oat flour are shown in Table 3. As the portion of oats flour incorporated in formulations, Calcium (Ca), Iron (Fe), Sodium $(\mathrm{Na})$ and Potassium $(\mathrm{K})$ contents were increased significantly $(p<0.05)$ in noodles (Aydin \& Gocmen, 2011). The difference of $\mathrm{Ca}, \mathrm{Fe}, \mathrm{Na}$ and $\mathrm{K}$ between the $\mathrm{S} 0$ (control) and S4 (35\% of oats flour) were 1.44, 1.10, 1.30 and 1.69 times, respectively. For this reason, oats and oats products were considered as a worthy contributor to the mineral needs of consumers (Webster, 2002).

The results of this study revealed that addition of OF $(\mathrm{S} 0<\mathrm{S} 1<\mathrm{S} 2<\mathrm{S} 3<\mathrm{S} 4)$ improved the nutrition value especially increases mineral contents significantly (Table 2). Therefore, the sample S4 (OF 35\% and WF $65 \%$ ) has showed superior formulation according to chemical composition. 


\subsection{Water absorption quality}

Water absorption of sample is the capability to hold water within its interior structure and it is affected by some other factors like protein quality, fiber content, damaged starch, physical properties of the flour etc. (Vollmann et al., 2004). The Water absorption percentage of S0, S1, S2, S3 and S4 were $142.48 \%, 144.90 \%, 146.35 \%, 152.32 \%$ and $156.15 \%$, respectively. The water absorption rate of S3 and S4 were significantly $(p<0.05)$ higher than the control noodles (S0) (Table 4). Previous studies showed that higher amount of $\beta$-Glucans found at oats flour than wheat flour and also the higher amount of $\beta$-glucan in oat flour was responsible for increased water absorption (Tiefenbacher, 2017; Niu et al., 2017).

\subsection{Cooking loss and volume increase quality of noodles}

Cooking quality is the most important characteristic to final consumers and therefore of great importance to noodle processors. In this study, the cooking loss increased significantly $(p<0.05)$ from $8.15 \%$ to $8.53 \%$ with the incorporation of OF in noodles (S1 to S4), whereas S0 lost 7.14\% (Table 4). It indicated that addition of oat flour was responsible for higher $(p<0.05)$ percentage of cooking loss compared to wheat flour (Izydorczyk et al., 2005). The variation in cooking quality was attributed mainly to gluten fraction and due to the disruption of the protein starch matrix (Bhise et al., 2015).

The percentage of volume increased of S0, S1, S2, S3, and S4 were $189.62 \%, 179.48 \%, 139.81 \%, 131.21 \%$ and $120.70 \%$, accordingly. The sample S4 showed maximum volume decreased $(p<0.05)$ from the control noodles (S0) (Table 4), i.e., being in accordance with previous study (Chauhan et al., 2018). Aydin et al., found that $10 \%$ of OF added noodles could increase maximum volume (238.46\%), however, replacing $20 \%, 30 \%$ and $40 \%$ of OF minimized $206.25 \%, 188.24 \%$ and $181.25 \%$ of swelling, respectively (Aydin \& Gocmen, 2011).

\subsection{Cooking time}

The ideal or optimum time of cooking food is defined by the required time to fully hydrate the food. Ideal cooking time is an important factor for snacks food (Sui et al., 2006). The ideal cooking time of S0, S1, S2, S3 and S4 were 1.56, 2.20, 2.25, 2.53 and $3.51 \mathrm{~min}$, respectively (Table 4). The result showed that noodles with an increasing percentage of protein with low gluten flour involved an extension of optimum cooking time which was consistent with the previous report (Bhise et al., 2015; Xu et al., 2020; Yao et al., 2020). Yao et al., reported that $8.0 \%$ of protein containing noodles required 2 min10s as optimum cooking time but higher protein containing noodles (14.0\%) required more time (3 min 5s) (Yao et al., 2020).

Table 4. Effect of oat flour on cooking quality of sample noodles.

\begin{tabular}{ccccc}
\hline Formulations & Water Absorption & Volume increase & Cooking time & Cooking loss \\
\hline S0 & $142.48 \pm 0.76^{\mathrm{c}}$ & $189.62 \pm 0.07^{\mathrm{a}}$ & $1.56 \pm 0.01^{\mathrm{a}}$ & $7.14 \pm 0.02^{\mathrm{a}}$ \\
\hline $\mathrm{S} 1$ & $144.90 \pm 0.36^{\mathrm{c}}$ & $179.48 \pm 0.06^{\mathrm{c}}$ & $2.20 \pm 0.07^{\mathrm{ac}}$ & $8.15 \pm 0.30^{\mathrm{b}}$ \\
\hline $\mathrm{S} 2$ & $146.35 \pm 0.81^{\mathrm{b}}$ & $139.81 \pm 0.05^{\mathrm{ad}}$ & $2.25 \pm 0.01^{\mathrm{d}}$ & $8.22 \pm 0.08^{\mathrm{b}}$ \\
\hline $\mathrm{S} 3$ & $152.32 \pm 0.69^{\mathrm{ab}}$ & $131.21 \pm 0.46^{\mathrm{b}}$ & $2.53 \pm 0.01^{\mathrm{b}}$ & $8.39 \pm 0.04^{\mathrm{c}}$ \\
\hline $\mathrm{S} 4$ & $156.15 \pm 0.79^{\mathrm{a}}$ & $120.70 \pm 0.17^{\mathrm{bc}}$ & $3.51 \pm 0.02^{\mathrm{c}}$ & $8.53 \pm 0.02^{\mathrm{b}}$ \\
\hline $\mathrm{CD}(p=0.05)$ & 0.195 & 0.009 & 0.030 & 0.001 \\
\hline
\end{tabular}

Values are means of triplicates \pm Standard Deviation.

\subsection{Sensory properties}

The mean values of the hedonic scores for sensory attributes of cooked noodles samples are shown in Table 5 with statistical analysis. The results showed that the texture, flavor, mouth feel and overall acceptance of formulations S1, S2, were not significantly different from S0. On the other hand, S3 (30\%OF: 70\%WF) was higher than S0 $(100 \% \mathrm{WF})$. It was a noticeable factor that lowest score of sensory evaluations found at sample S4 (35\% OF: 65\% 
WF) which contained highest amount of oats flour among other samples (Table 1). The picture of cooked noodles could produce dark brown colour and braked down into small pieces instead of forming a long shape (Figure 4).

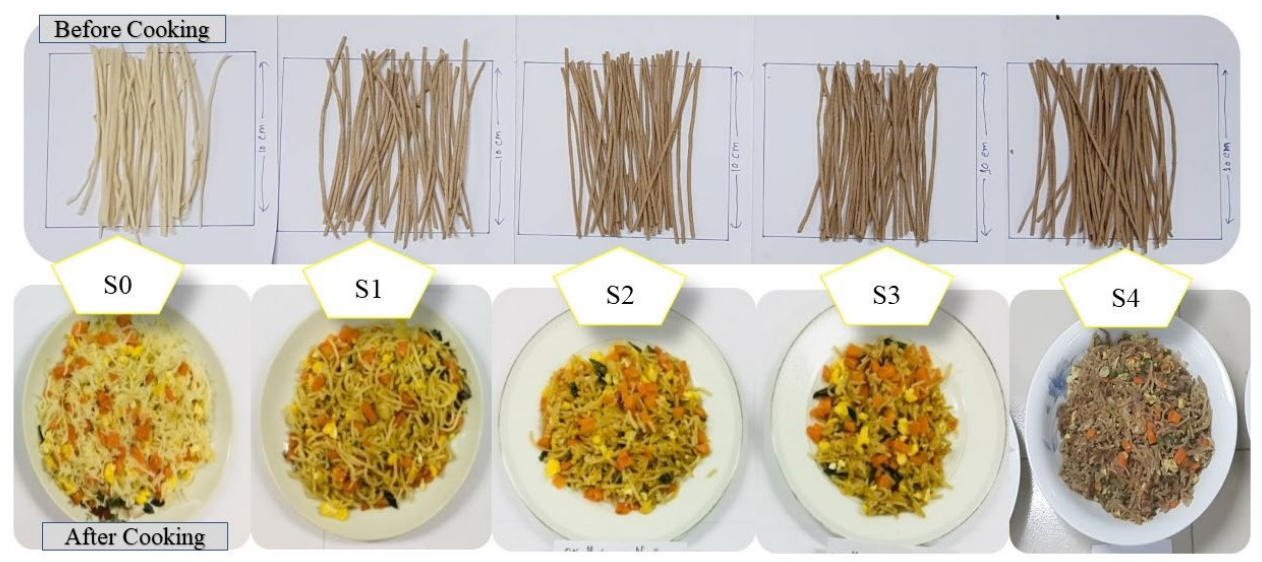

Figure 4. Dried and cooked noodles fortified with different percentages of oats flour: S0, S1, S2, S3, S4 contains $0: 100,20: 80,25: 75,30: 70$ and 35:65 percentage of oat and wheat flour, respectively.

It could be noted that more OF containing noodles have shown a tendency to breakdown its structure even during boiling or cooking (Chauhan et al., 2018) and oats affected adversely the color of noodles (become dark brown color) due to high fiber content (Guo et al., 2018; Reungmaneepaitoon et al., 2006). Among the noodles formulations, the sample with $30 \%$ of oat flour (S3) exhibited statistically $(p<0.05)$ higher qualitative attributes than the control (S0) during sensory evaluation (Table 5).

Table 5. Sensorial attributes of noodles supplemented with oat flour.

\begin{tabular}{ccccccc}
\hline Formulations & Color & Texture & Flavor & Mouth feel & Taste & Overall Acceptance \\
\hline S0 & $8.57 \pm 0.53^{\mathrm{a}}$ & $7.57 \pm 0.98^{\mathrm{b}}$ & $7.57 \pm 0.98^{\mathrm{a}}$ & $7.00 \pm 1.53^{\mathrm{b}}$ & $7.29 \pm 0.11^{\mathrm{a}}$ & $7.14 \pm 0.21^{\mathrm{c}}$ \\
\hline $\mathrm{S} 1$ & $7.71 \pm 0.25^{\mathrm{b}}$ & $7.71 \pm 0.25^{\mathrm{c}}$ & $7.57 \pm 0.98^{\mathrm{a}}$ & $7.57 \pm 0.27^{\mathrm{a}}$ & $7.43 \pm 0.13^{\mathrm{b}}$ & $7.57 \pm 0.98^{\mathrm{e}}$ \\
\hline $\mathrm{S} 2$ & $7.57 \pm 0.98^{\mathrm{b}}$ & $7.57 \pm 0.98^{\mathrm{c}}$ & $7.29 \pm 0.11^{\mathrm{a}}$ & $7.86 \pm 0.07^{\mathrm{c}}$ & $7.57 \pm 0.98^{\mathrm{c}}$ & $7.00 \pm 0.53^{\mathrm{a}}$ \\
\hline $\mathrm{S} 3$ & $8.57 \pm 0.53^{\mathrm{b}}$ & $9.00 \pm 0.00^{\mathrm{a}}$ & $8.43 \pm 0.53^{\mathrm{a}}$ & $8.71 \pm 0.49^{\mathrm{c}}$ & $8.86 \pm 0.38^{\mathrm{e}}$ & $8.71 \pm 0.49^{\mathrm{b}}$ \\
\hline $\mathrm{S} 4$ & $6.71 \pm 0.76^{\mathrm{c}}$ & $7.29 \pm 0.38^{\mathrm{d}}$ & $6.7 \pm 0.95^{\mathrm{b}}$ & $6.0 \pm 0.58^{\mathrm{c}}$ & $8.86 \pm 0.38^{\mathrm{d}}$ & $7.00 \pm 0.82 \mathrm{~d}$ \\
\hline $\mathrm{CD}(p=0.05)$ & 0.398 & 0.034 & 0.746 & 0.942 & 0.048 & 0.049 \\
\hline
\end{tabular}

Values are means of triplicates \pm Standard Deviation.

\section{Conclusions}

According to the present study, noodles manufactured with a combination of $70 \%$ of wheat flour and $30 \%$ of oat flour with optimized ingredients may keep good organoleptic and cooking quality attributes as well as nutritional properties. This formulation resulted in a higher amount of protein, fiber and minerals $(\mathrm{Ca}, \mathrm{Fe}, \mathrm{Na}$ and $\mathrm{K})$ but lower carbohydrate content than noodle $100 \%$ wheat flour. Then, oat supplemented noodles up to $30 \%$ may be considered for commercialization considering its nutritional benefits. However, the main constraints for commercialization may be product color and cooking loss that must be improved by further research. More than $30 \%$ of oat flour will deform the noodles, therefore, maximum 30:70 (oat flour: wheat flour) ratio should be consider as the best formulation.

\section{Acknowledgements}

The authors are thankful to the Department of Nutrition and Food Engineering, Daffodil International University and Institute of Food Science \& Technology, Bangladesh Council of Scientific \& Industrial Research (BCSIR) for their supports. 


\section{References}

Ahmad, A., Anjum, F. M., Zahoor, T., Nawaz, H., \& Ahmed, Z. (2010). Extraction and characterization of $\beta$-d-glucan from oat for industrial utilization. International Journal of Biological Macromolecules, 46(3), 304-309. PMid:20083136. http://dx.doi.org/10.1016/j.ijbiomac.2010.01.002

American Association of Cereal Chemists - AACC. (2010). Approved methods of the American Association of Cereal Chemists St. Paul: AACC International. Retrieved in 2017, August 4, from http://methods.aaccnet.org/toc.aspx

Asenstorfer, R. E., Wang, Y., \& Mares, D. J. (2006). Chemical structure of flavonoid compounds in wheat (Triticum aestivum L.) flour that contribute to the yellow colour of Asian alkaline noodles. Journal of Cereal Science, 43(1), 108-119. http://dx.doi.org/10.1016/j.jcs.2005.09.001.

Aydin, E., \& Gocmen, D. (2011). Cooking quality and sensorial properties of noodle supplemented with oat flour. Food Science and Biotechnology, 20(2), 507-511. http://dx.doi.org/10.1007/s10068-011-0070-1

Bhalerao, P. P., Chaudhari, N. S., Muley, A. B., Talib, M. I., Parate, V. R., \& Kudake, D. C. (2018). Fortification of wheat flour with ragi flour: Effect on physical, nutritional, antioxidant and sensory profile of noodles. Current Research in Nutrition and Food Science, 6(1), 165-173.http://dx.doi.org/10.12944/CRNFSJ.6.1.19

Bhise, S., Kaur, A., \& Aggarwal, P. (2015). Development of protein enriched noodles using texturized defatted meal from sunflower, flaxseed and soybean. Journal of Food Science and Technology, 52(9), 5882-5889. PMid:26345004. http://dx.doi.org/10.1007/s13197-014-1630-1

Chakraborty, M., Hareland, G. A., Manthey, F. A., \& Berglund, L. R. (2003). Evaluating quality of yellow alkaline noodles made from mechanically abraded sprouted wheat. Journal of the Science of Food and Agriculture, 83(5), 487-495. http://dx.doi.org/10.1002/jsfa.1403

Chauhan, D., Kumar, K., Kumar, S., \& Kumar, H. (2018). Effect of incorporation of oat flour on nutritional and organoleptic characteristics of bread and noodles. Current Research in Nutrition and Food Science Journal, 6(1), 148-156. http://dx.doi.org/10.12944/CRNFSJ.6.1.17.

Choo, C. L., \& Aziz, N. A. A. (2010). Effects of banana flour and $\beta$-glucan on the nutritional and sensory evaluation of noodles. Food Chemistry, 119(1), 34-40. http://dx.doi.org/10.1016/j.foodchem.2009.05.004

Eneche, E. H. (1999). Biscuit-making potential of millet/pigeon pea flour blends. Plant Foods for Human Nutrition, 54(1), 21-27. PMid:10646626. http://dx.doi.org/10.1023/A:1008031618117

Guo, Q., Kang, J., Bai, Y., \& Xu, F. (2018). Dietary fiber: Chemistry, structure, and properties. Journal of Chemistry, $2018,1-2$. http://dx.doi.org/10.1155/2018/1328797

Horwitz, W., \& Latimer, G. W. (2005). Official methods of analysis of AOAC International. Gaithersburg: AOAC International.

Hou, Q., Li, Y., Li, L., Cheng, G., Sun, X., Li, S., \& Tian, H. (2015). The metabolic effects of oats intake in patients with type 2 diabetes: A systematic review and meta-analysis. Nutrients, 7(12), 10369-10387. PMid:26690472. http://dx.doi.org/10.3390/nu7125536

Izydorczyk, M. S., Lagassé, S. L., Hatcher, D. W., Dexter, J. E., \& Rossnagel, B. G. (2005). The enrichment of Asian noodles with fiber-rich fractions derived from roller milling of hull-less barley. Journal of the Science of Food and Agriculture, 85(12), 2094-2104. http://dx.doi.org/10.1002/jsfa.2242

Kudake, D. C., Pawar, A. V., Muley, A. B., Parate, V. R., \& Talib, M. I. (2017). Enrichment of wheat flour noodles with oat flour: Effect on physical, nutritional, antioxidant and sensory properties. International Journal of Current Microbiology and Applied Sciences, 6(12), 204-213. http://dx.doi.org/10.20546/ijcmas.2017.612.026

Kulkarni, S. S., Desai, A. D., Ranveer, R. C., \& Sahoo, A. K. (2012). Development of nutrient rich noodles by supplementation with malted ragi flour. International Food Research Journal, 19(1), 309. Retrieved in 2017, August 4, from http://www.ijoart.org/docs/DEVELOPMENT-OF-NUTRIENTRICH-NOODLES-BY-SUPPLEMENTATION-WITH-MALTED-KODOMILLET-FLOUR.pdf

Liu, S., Sun, Y., Obadi, M., Jiang, Y., Chen, Z., Jiang, S., \& Xu, B. (2020). Effects of vacuum mixing and mixing time on the processing quality of noodle dough with high oat flour content. Journal of Cereal Science, 91, 102885 http://dx.doi.org/10.1016/j.jcs.2019.102885

Mahmoud, E. A., Nassef, S. L., \& Basuny, A. M. (2012). Production of high protein quality noodles using wheat flour fortified with different protein products from lupine. Annals of Agricultural Science, 57(2), 105-112. http://dx.doi.org/10.1016/j.aoas.2012.08.003

Majzoobi, M., Layegh, B., \& Farahnaky, A. (2014). Inclusion of oat flour in the formulation of regular salted dried noodles and its effects on dough and noodle properties. Journal of Food Processing and Preservation, 38(1), 48-58 http://dx.doi.org/10.1111/j.1745-4549.2012.00742.x

Manzoor, M. S., Pasha, I., Shehzad, A., Zia, M. A., \& Zhu, M. J. (2020). Antioxidant profiling of indigenous oat cultivars with special reference to avenanthramides. International Food Research Journal, 27(2), 261-269. Retrieved in 2017, August 4, from https://www.cabdirect.org/globalhealth/abstract/20203241436

Mertens, D. (2005). AOAC official method 975.03: Metal in plants and pet foods. In W. Horwitz \& G. W. Latimer (Eds.), Official methods of analysis (18th ed., Chap. 3, pp. 3-4). Gaitherburg: AOAC International. Retrieved in 2017, August 4, from https://www.worldcat.org/title/official-methods-of-analysis-of-aoac-international/oclc/62751475

Niu, Q., Pu, Y., Li, X., Ma, Z., \& Hu, X. (2017). Solvent retention capacities of oat flour. International Journal of Molecular Sciences, 18(3), 590. PMid:28335393. http://dx.doi.org/10.3390/ijms18030590 
Oghbaei, M., \& Prakash, J. (2013). Effect of fractional milling of wheat on nutritional quality of milled fractions. Trends in Carbohydrate Research, 5(1). Retrieved in 2017, August 4, from http://www.trendscarbo.com/shoppingcart.php

Oghbaei, M., \& Prakash, J. (2016). Effect of primary processing of cereals and legumes on its nutritional quality: A comprehensive review. Cogent Food \& Agriculture, 2(1), 1136015. http://dx.doi.org/10.1080/23311932.2015.1136015

Parvin, R., Farzana, T., Mohajan, S., Rahman, H., \& Rahman, S. S. (2020). Quality improvement of noodles with mushroom fortified and its comparison with local branded noodles. NFS Journal, 20, 37-42. http://dx.doi.org/10.1016/j.nfs.2020.07.002.

Pearson, D. (1999). Pearsons composition and analysis of foods (pp. 117-123). Reading: University of Reading. Retrieved in 2017, August 4, from http://ludibuk.com/pearson_analysis_of_foods.pdf

Perrelli, A., Goitre, L., Salzano, A. M., Moglia, A., Scaloni, A., \& Retta, S. F. (2018). Biological activities, health benefits, and therapeutic properties of avenanthramides: From skin protection to prevention and treatment of cerebrovascular diseases. Oxidative Medicine and Cellular Longevity, 2018, 6015351. PMid:30245775. http://dx.doi.org/10.1155/2018/6015351

Reungmaneepaitoon, S., Sikkhamondhol, C., \& Tiangpook, C. (2006). Nutritive improvement of instant fried noodles with oat bran. Songklanakarin Journal of Science and Technology, 28(Suppl. 1), 89-97. Retrieved in 2017, August 4, from https://www.semanticscholar.org/paper/Nutritive-improvement-of-instant-fried-noodles-withReungmaneepaitoon/d4abc77841e233231f1f18c5ee9cffa27bd72212

Sánchez-Peña, M. J., Márquez-Sandoval, F., Ramirez-Anguiano, A. C., Velasco-Ramirez, S. F., Macedo-Ojeda, G., \& Gonzalez-Ortiz, L. J. (2017). Calculating the metabolizable energy of macronutrients: A critical review of Atwater's results. Nutrition Reviews, 75(1), 37-48. PMid:27974598. http://dx.doi.org/10.1093/nutrit/nuw044

Shukla, K., \& Srivastava, S. (2014). Evaluation of finger millet incorporated noodles for nutritive value and glycemic index. Journal of Food Science and Technology, 51(3), 527-534. PMid:24587528. http://dx.doi.org/10.1007/s13197-011-0530-x

Singh, C., Singh, B., Satpal, P. K., Ankush, M., Gora, K., \& Kumar, A. (2019). Micronutrient management for enhancing production of major fodder crops: A review. Forage Research, 45(2), 95-102. Retrieved in 2017, August 4, from http://forageresearch.in/micronutrient-management-for-enhancing-production-of-major-fodder-crops-a-review/

Siong, T. E., Choo, K. S., \& Shahid, S. M. (1989). Determination of iron in foods by the atomic absorption spectrophotometric and colorimetric methods. Pertanika, 12(3), 313-322. Retrieved in 2017, August 4, from http://www.pertanika.upm.edu.my/Pertanika\%20PAPERS/PERT\%20Vol.\%2012\%20(3)\%20Dec.\%201989/05\%20Pertanika\%20 Vol.12\%20(3)\%20Dec.\%201989\%20(Pg\%20315-322).pdf

Snedecor, G. W., \& Cochran, W. G. (1994). Statistical methods (8th ed.). Ames: lowa State University Press. Retrieved in 2017 , August 4, from https://journals.sagepub.com/doi/abs/10.3102/10769986019003304

Somvanshi, A., Patel, A., \& Jalgaonwala, R. (2017). Effect of microbial fermentation and processing on nutritional and antinutritional properties of selected fermented foods. Asian Journal of Research in Chemistry, 10(4), 531-540. http://dx.doi.org/10.5958/0974-4150.2017.00088.8

Sui, Z., Lucas, P. W., \& Corke, H. (2006). Optimal cooking time of noodles related to their notch sensitivity. Journal of Texture Studies, 37(4), 428-441. http://dx.doi.org/10.1111/j.1745-4603.2006.00061.x

Thies, F., Masson, L. F., Boffetta, P., \& Kris-Etherton, P. (2014). Oats and CVD risk markers: A systematic literature review. British Journal of Nutrition, 112(Suppl. 2), S19-S30. PMid:25267241. http://dx.doi.org/10.1017/S0007114514002281

Tiefenbacher, K. F. (2017). Technology of main ingredients: water and flours. In K. F. Tiefenbacher (Ed.), Wafer and waffle: Processing and manufacturing (pp. 15-121). San Diego: Academic Press. Retrieved in 2017, August 4, from https://www.sciencedirect.com/science/article/pii/B9780128094389000028

Vollmann, J., Grausgruber, H., \& Ruckenbauer, P. (Eds.). (2004). Genetic variation for plant breeding. In Proceedings of the 17th EUCARPIA General Congress. Vienna: University of Natural Resources and Applied Life Sciences. Retrieved in 2017, August 4, from https://zenodo.org/record/1204819/files/Vollmann_Grausgruber_Ruckenbauer_2004_EUCARPIA_XVII.pdf

Webster, F. H. (2002). Whole-grain oats and oat products: Whole-grain foods in health and disease (pp. 83-123). St. Paul: American Association of Cereal Chemists. Retrieved in 2017, August 4, from https://wholegrainscouncil.org/sites/default/files/atoms/files/Slavin Article 0504.pdf

Welch, R. W. (1995). The chemical composition of oats. In R. W. Welch (Ed.), The oat crop (World Crop Series). Springer: Dordrecht. http://dx.doi.org/10.1007/978-94-011-0015-1_10.

Xu, M., Hou, G. G., Ma, F., Ding, J., Deng, L., Kahraman, O., Niu, M., Trivettea, K., Lee, B., Wu, L., \& Baik, B.-K. (2020). Evaluation of aleurone flour on dough, textural, and nutritional properties of instant fried noodles. LWT, 126, 109294. http://dx.doi.org/10.1016/j.Iwt.2020.109294.

Yao, M., Li, M., Dhital, S., Tian, Y., \& Guo, B. (2020). Texture and digestion of noodles with varied gluten contents and cooking time: The view from protein matrix and inner structure. Food Chemistry, 315, 126230. PMid:32014665.

http://dx.doi.org/10.1016/j.foodchem.2020.126230

Funding: None. 